\begin{tabular}{|c|c|c|c|}
\hline $\begin{array}{c}\text { RESEARCH } \\
\text { ARTICLE }\end{array}$ & $\begin{array}{r}\text { ADVANCE RESEARC } \\
\text { volume } 8 \mid \text { Issu }\end{array}$ & OCIAL SCIENCE & \\
\hline $0=$ & DOI: 10.15740/HAS/ARJSS/8.1/37-41 & Visit us : www.researchjournal.co.in & \\
\hline
\end{tabular}

\title{
Parental and peer influence on aggressive behaviour of selected higher secondary students
}

Ranu Saikia and P. Jagathambal*

Department of Human Development, Avinashilingam Institute for Home Science and Higher Education for Women, COIMBATORE (T.N.) INDIA

\begin{tabular}{lrl}
\multicolumn{2}{l}{ ARTICLE INFO : } \\
\hline Received & $:$ & 24.10 .2016 \\
Revised & $:$ & 12.04 .2017 \\
Accepted & $:$ & 27.04 .2017
\end{tabular}

\section{KEY WORDS :}

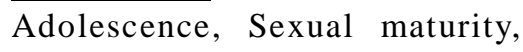
Aggressive behaviour, Higher secondary students

HOW TO CITE THIS ARTICLE : Saikia, Ranu and Jagathambal, P. (2017). Parental and peer influence on aggressive behaviour of selected higher secondary students. Adv. Res. J. Soc. Sci., 8 (1) : 3741, DOI: 10.15740/HAS/ARJSS/8.1/3741.

*Author for correspondence

\begin{abstract}
Adolescence is a development stage in human life which begins with puberty, the period where sexual maturity occurs and attains emotional, social and other aspects of adult maturity (Kale, 2008). Adolescents are inadequate in life skills such as problemsolving, conflict resolution, communication, anger management. Therefore, it can be said that adolescents are often faced with various developmental problems during this period and these problems may lead to aggression as they have no alternative behaviours. The term "aggression" refers to a range of behaviours that can result in both physical and psychological harm to oneself, other or objects in the environment. The expression of aggression can occur in a number of ways, including verbally, mentally and physically (Cherry, 2009). There are also views that suggest aggression to be formed from the interaction of individual characteristics like low self-esteem, peer rejection and academic failure and environmental characteristics like poverty; limited social support. Aggressive behaviour is slowly gaining prevalence among adolescents. So, the investigator has undertaken the study on "Parental and peer influence on aggressive behaviour of selected higher secondary students"with 50 boys and 50 girls by using a formulated questionnaire to analyze the factors that lead to aggression among learners in Secondary Schools
\end{abstract}

